\title{
PERAN KEBERHASILAN E-CRM TERHADAP E-LOYALTY
}

\author{
Angelita Nauli Panggabean - 2301950881 - LB21
}

E-Business Strategy and Implementation

\begin{abstract}
Abstrak
Perkembangan teknologi telah mendorong perusahaan untuk menggunakan internet dalam menjangkau pelanggan dan juga mengelola hubungan perusahaan dengan pelanggan. Namun, untuk menjalin hubungan yang lebih dalam dan baik antara perusahaan dan pelanggan tidaklah mudah. Dengan begitu, perusahaan perlu menerapkan strategi E-CRM untuk menarik, mempertahankan, dan meningkatkan hubungan pelanggan. Tujuan dari karya tulis ini adalah untuk melihat peran keberhasilan E-CRM terhadap e-loyalty pelanggan. Untuk mencapai kesimpulan, peneliti menggunakan metode tinjauan pustaka, dimana peneliti mencari dan mengumpulkan jurnal-jurnal, baik nasional maupun internasional melalui internet. Hasil yang ditemukan adalah bahwa keberhasilan E-CRM berpengaruh positif dan signifikan terhadap e-loyalty.
\end{abstract}

Kata Kunci: e-CRM, e-Loyalty

\section{Pendahuluan}

Pesatnya perkembangan teknologi mengakibatkan persaingan bisnis yang pesat, banyak perusahaan yang mulai berjualan dan memasarkan produknya melalui saluran online. Persaingan yang kompetitif saat ini, sangat penting untuk menerapkan semua upadaya untuk menarik pelanggan potensial dan juga mempertahankan pelanggan saat ini (Dehghanpouri et al., 2020). Dengan begitu, perusahaan perlu mengetahui langkah yang tepat untuk terus memberikan layanan terbaik kepada pelanggan di internet untuk meningkatkan loyalitasnya. Langkah yang tepat ini diharapkan akan membantu perusahaan untuk tetap unggul dan mampu bersaing dengan perusahaan lain yang sejenis (Saroso et al., 2019; Suharsono et al., 2021). Salah satu langkah yang dapat perusahaan lakukan adalah dengan membangun hubungan yang baik dengan pelanggan atau dengan customer relationship management (CRM). Customer relationship management atau manajemen hubungan pelanggan didefinisikan sebagai proses dalam membangun dan memelihara hubungan pelanggan yang menguntungkan dengan memberikan nilai, serta memastikan bahwa pelanggan puas (Suharsono et al., 2021). E-CRM mengacu pada manajemen hubungan pelanggan elektronik atau dengan kata lain CRM yang berbasis web yang dimana hubungannya dilakukan secara elektronik. Tujuan utama dari E-CRM ini adalah untuk mengindentifikasi dan mempertahankan pelanggan yang tepat untuk memicu penggunaan berulang atas produk atau jasa yang ditawarkan oleh perusahaan (Suharsono et al., 2021). Dengan begitu, E-CRM akan menciptakan e-loyalty atau keinginan pelanggan untuk kembali ke situs web, baik untuk melakukan pembelian atau pun tidak. Penelitian ini bertujuan untuk mengetahui apakah E-CRM yang berhasil diterapkan memiliki pengaruh terhadap terbentuknya e-loyalty. 


\section{Tinjauan Pustaka}

\section{E-CRM}

Customer relationship management (CRM) atau manajemen hubungan pelanggan adalah proses pengelolaan informasi rinci dan teliti yeng berkaitan dengan pelanggan untuk menciptakan loyalitas pelanggan yang baik (Racbhini et al., 2021). CRM ini dianggap sangat penting karena berperan sebagai penggerak utama profitabilitas perusahaan. CRM memungkinkan perusahaan untuk menyediakan layanan pelanggan dengan real-time. Di era digital, menyediakan beberapa alat baru untuk mengembangkan CRM, mulai dari iklan dan video online, situs web, aplikasi, iklan seluler, komunitas online, serta platform media sosial (Kotler and Armstrong, 2018). Era digital ini membuat CRM untuk bertransformasi menjadi E-CRM. E-CRM mengacu pada penggunaan teknologi komunikasi digital untuk meningkatkan hubungan perusahaan dengan pelanggan yang sudah ada dan untuk meningkatkan penggunaan layanan online (Suharsono et al., 2021). Konsep dasar E-CRM sendiri adalah CRM yang berbasis elektonik.

Saat ini, banyak perusahaan yang cenderung berfokus pada manajemen pelanggan daripada menajemen merek (Rachbini et al., 2019). Penerapan E-CRM ini akan menghasilkan nilai yang baik bagi perusahaan dan pelanggan, sehingga E-CRM adalah cara terbaik bagi organisasi untuk mempertahankan hubungan yang baik. Berdasarkan (Sasono et al., 2021), bahwa fungsi E-CRM tidak hanya sebagai sebuah call center atau help desk, melainkan juga digunakan sebagai penghubung antara perusahaan dan setiap pelanggan untuk meningkatkan e-loyalitas. Hasil penelitian (Sasono et al., 2021) pun menunjukkan bahwa E-CRM berpengaruh positif yang signifikan terhadap e-loyalitas. Oleh karena itu, keberhasilan E-CRM akan menciptakan loyalitas pelanggan terhadap suatu merek, produk, atau layanan (Dehghanpouri et al., 2020).

\section{E-Loyalty}

Loyalitas atau loyalty didefinisikan sebagai komitmen yang dimiliki pelanggan untuk membeli kembali suatu produk atau jasa yang disukai di masa yang akan datang (Racbhini et al., 2021). Loyalitas juga adalah hubungan berkelanjutan antara pelanggan dan sebuah merek. Hal ini dapat dilhat dari penolakan untuk beralih ke merek lain. Perkembangan teknologi telah membuat konektivitas, dan kini loyalitas bukan hanya sekedar retensi pelanggan, melainkan juga sebagai pelanggan yang bersedia memberikan rekomendasi positif kepada konsumen lain. Berdasarkan definisi di atas, loyalitas berbasis elektronik atau e-loyalty merupakan konsisten perilaku pelanggan untuk melakukan pembelian ulang dan memberikan rekomendasi kepada konsumen lain (Racbhini et al., 2021). Menurut Kotler dan Keller (2016), menggambarkan pelanggan yang setia adalah pelanggan yang selalu mengonsumsi atau menggunakan merek tertentu selama produk dan jasa dari merek tertentu nmasih tersedia. Dengan begitu, konsep e-loyalty ini pun dapat 
didefinisikan sebagai komitmen pelanggan untuk membeli kembeli suatu produk atau layanan di masa depan melalui platform elektronik. Konsep E-CRM telah menjadi strategi dalam membangun relasi dan alat komunikasi perusahaan dan pelanggan. Penelitian mengungkapkan bahwa penerapan E-CRM berdampak positif terhadap e-loyalty dalam membangun hubungan dengan konsumen. Integrasi teknologi, proses, dan aktivitas bisnis lainnya di lingkungan pelanggan, memfasilitasi aplikasi CRM untuk membantu organisasi mengenali pelanggan dengan baik, meningkatkan kepuasan, dan loyalitas pelanggan terhadap layanan dan produk yang ditawarkan.

\section{Metode}

Karya tulis ini dibuat dengan metode literature review atau tinjauan pustaka, dimana penulis mengumpulkan dan mempelajari jurnal-jurnal untuk mencapai kesimpulan. Jurnal tersebut terdiri dari jurnal mengenai $e-C R M$ dan $e$-Loyalty yang didapatkan dari berbagai sumber melalui internet untuk mendapat kesimpulan.

\section{Kesimpulan}

Saat ini, teknologi informasi dan komunikasi dimanfaatkan secara maksimal untuk mencapai efisiensi, sehingga menghasilkan model bisnis baru berbasis digital. Upaya yang dapat dilakukan oleh perusahaan demi keberhasilan perusahaan adalah dengan fokus membangun hubungan dengan pelanggan. Jika membangun hubungan yang baik dengan pelanggan, maka akan tercipta loyalitas pelanggan. Dalam bisnis digital, manajemen hubungan pelanggan disebut sebagai E-CRM. Meningkatkan hubungan dengan pelanggan menempatkan E-CRM sebagai fenomena revolusioner dalam industri bisnis. Manfaat dari implementasi E-CRM yang sukses adalah peningkatan loyalitas pelanggan. Kriteria penting dalam keberhasilan E-CRM, antara lain akuisisi pelanggan, retensi, kepuasan, dan loyalitas. Berdasarkan penelitian (Riyadi et al., 2021; Sasono et al., 2021), bahwa E-CRM memiliki pengaruh terhadap e-loyalty. Dengan demikian, keberhasilan sebuah E-CRM memiliki peran penting dalam membangun e-loyalty.

\section{Reference:}

Dehghanpouri, H., Soltani, Z., \& Rostamzadeh, R. (2020). The Impact of Trust, Privacy and Quality of Service on The Success of E-CRM: The Mediating Role of Customer Satisfaction. Journal of Business and Industrial Marketing, 35(11), 1831-1847. https://doi.org/10.1108/JBIM-07-2019-0325

Racbhini, W., Wulandjani, H., Thalib, S., Setiyowati, H., \& Sasmito, T. (2021). Effect of ECRM and E-Servqual on E-Loyalty through E-Satisfaction in Millennial Generation, Study of Online Shopping Behavior in Indonesia. International Journal of Economic and Business Applied, 2(2), 2021. http://ijeba.makarioz.org/

Rachbini, W., Hatta, I. H., \& Evi, T. (2019). Determinants of Trust and Customer Loyalty on C2C E-Marketplace in Indonesia. International Journal of Civil Engineering and Technology (IJCIET), 10(03), 116-127. 
Riyadi, S., Abdi Khairusy, M., Sunarsi, D., Nur Sholeh, A., Erlangga, H., \& Grace Haque, M. (2021). Effect of E-Marketing and E-CRM on E-Loyalty: An Empirical Study on Indonesian Manufacteres. Turkish Journal of Physiotherapy and Rehabilitation, 32(3). www.turkjphysiotherrehabil.org

Saroso, H., Hida Syahchari, D., Sudrajat, D., \& Grace Herlina, M. (2019). E-Service Quality and Corporate Image on Customer Perception. In International Journal of Innovation, Creativity and Change. www.ijicc.net (Vol. 10, Issue 8). www.ijicc.net

Sasono, I., Suroso, \& Novitasari, D. (2021). A Study on The Relationship of E-arketing, E-CRM, and E-loyalty: Evidence From Indonesia. International Journal of Data and Network Science, 5(2), 115-120. https://doi.org/10.5267/j.ijdns.2021.2.003

Suharsono, J., Musriati, T., Fauziah, F., \& Dahny, R. U. (2021). The Role of Marketing and eCRM on e-Loyalty and Performance. Review of International Geographical Education, 11(10). www.rigeo.org 